\title{
Detection of Oil Slicks in the Adriatic Sea (Mediterranean) Using Satellite SAR Imagery
}

\author{
By Marinko Oluic ${ }^{*}$, Mira Morović ${ }^{ \pm} \&$ Andrei Ivanov ${ }^{\star}$
}

\begin{abstract}
The goal of this paper was the detection and mapping of oil slicks in the Adriatic Sea (Mediterranean) related to bottom seeps, using a series of 34 Envisat and Radarsat-2 SAR images from the period 2003-2013. The images were analyzed using SCANEX' web-GIS GeoMixer tool. The registered oil slicks were sorted by years and by categories, indicating natural seeps with high, mid or low probability. The recurrent slicks at some places are sings of natural seepage phenomena and generally correspond to areas where crude oil may leak from seabed seeps, in accordance with tectonic and seismic information revealed.
\end{abstract}

Keywords: Adriatic Sea, Satellite imagery, Oil slicks/seeps Detection

\section{Introduction}

The Adriatic Sea is a semi-enclosed part of the Mediterranean, covering the area of about 138,600 $\mathrm{km}^{2}$ (Lušić and Kos 2006). In Croatian part of the Adriatic Sea many geological and geophysical studies were carried out including exploratory drilling, which proved presence of oil and gas in some areas. The gas has been exploited in the North Adriatic Sea since the 80s of the last century.

Various remote sensing techniques were used in many areas of the world to detect natural oil seeps at the sea floor. Satellite remote sensing could be the best approach to more accurate estimate of natural oil seepage rates, and according to Kvenvolden and Cooper (2003) natural seeps account for about $47 \%$ of the crude oil entering the marine environment. It is well known that microwave sensors have the advantage for oil slick detection due to the unique sensitivity of the radar signal to the small-scale roughness (short-scale wind induced waves) of the sea surface (Topouzelis et al. 2007, Akar et al. 2011). Radar backscattering levels decrease on slicks and they appear as a dark patches with lower backscatter from the sea surface (Girard-Ardhuin et al. 2003). Therefore, systematic and global applications of satellite images can help locate natural oil seeps and improve estimates of seepage rates into the oceans ( $\mathrm{Hu}$ et al. 2009). It is also possible to distinguish between anthropogenic oil spills, natural seepage slicks and look-alikes using semi-automatic discrimination and visual inspection of detected dark spots (Bayramov et al. 2018).

In the world seas the oil slick detection and mapping based on satellite data were often used for hydrocarbon exploration and oil seeps detection, such as in the

\footnotetext{
*Adviser, GeoSat Co, Croatia.

${ }^{ \pm}$Consultant, Institute of Oceanography and Fisheries, Croatia.

${ }^{*}$ Researcher, Shirshov Institute of Oceanology, Russian Academy of Sciences, Russia.
} 
Gulf of Mexico (Friedman et al. 2002), the South Caspian Sea (Zatyagalova et al. 2007, Ivanov and Zatyagalova 2008), the Black Sea (Evtushenko and Ivanov 2013), Australian shelf (O'Brein et al. 2005), Santa Barbara Channel, California (Leifer et al. 2006), Lake Baikal (Ivanov 2012) etc.

Registered oil slicks and oil spills in Middle Adriatic mostly appear from anthropogenic sources (ships) or biogenic sources like phytoplankton blooms (Morović and Ivanov 2011, Morović et al. 2014, Morović et al. 2015). However, part of these oil slicks may be related to natural seepage.

Main geo-tectonic framework of the Adriatic Sea resulted as the disintegration of the Adriatic micro-plate. It is sinking below the Eurasian tectonic plate, accompanied by frequent, though not particularly intense seismic activity. We supposed that leaking of the oil might occur through a local fracture zones in the sea floor bedrock. This would be seen as oil slicks on he sea surface and could be indication of oil deposits. In addition, the gas seeps may possibly be linked to salt structures in the Middle Adriatic.

Detection of marine seepage with Synthetic Aperture Radar (SAR) could provide the first indication of undersea petroleum systems. Performed analysis of Envisat SAR images showed that there are many small size dark surface manifestations (slicks) visible on SAR images acquired at low wind conditions.

The main goal of this investigation was detection, mapping and identification of natural oil slick/seep manifestations, and their spreading in the Middle Adriatic, based on the SAR satellite data, performed for the first time in the Croatian waters (Oluić et al. 2014).

\section{Study Area}

The study area is the Middle Adriatic, encompassing more than $17,000 \mathrm{~km}^{2}$ (Figure 1).

Figure 1. (Left) The Satellite Mosaic of the Mediterranean; (Right) The Location of Investigated Area (Black Polygon) at the Adriatic Bathymetry Map
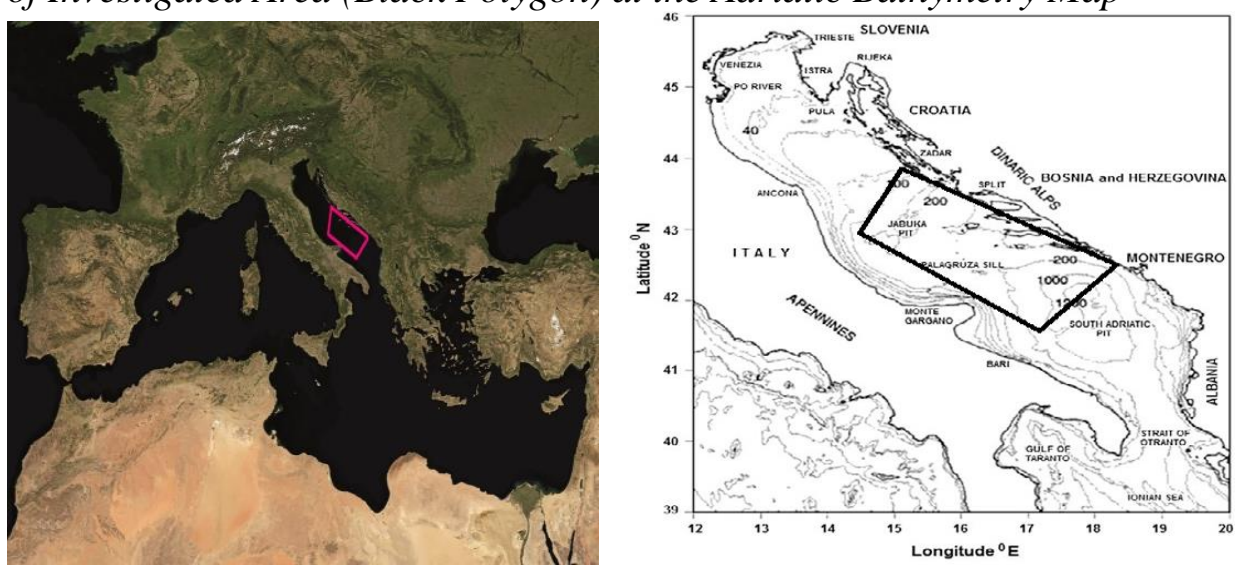

However, the investigated area was somewhat wider due to a different coverage of the satellite images, which allowed better locating of oil phenomena relative to the coast and islands. 
The investigated area spreads over the Middle Adriatic covering Jabuka Trough and Palagruža Sill and extends partly to the Southern Adriatic Basin. Bathymetry over the Adriatic axis crossing the area along the marked polygon gradually deepens from the isobaths $100 \mathrm{~m}$ to 1,200 $\mathrm{m}$ depth.

\section{Tectonic and Seismic Activity of the Adriatic Seabed and Oil Origin}

\section{Tectonics}

The Adriatic Basin is detached part of the African tectonic plate, known as Adriatic micro-plate (Devoti et al. 2002, Battaglia et al. 2004). The African and Eurasian plates started to collide at Early Cenozoic and collision between these plates has continued up to the present time (Volpi 2017). The Adriatic micro-plate has been subducted beneath the Eurasian plate and is still sinking toward north and northeast at a rate of about $4 \mathrm{~mm} /$ year (Oluic 2015). The structure and topography of the Adriatic microplate is dominated by the collision of these two plates. The rocks in the Adriatic micro-plate have sedimented over the crystalline complex in submerged depressions. Approximate depth of crystalline basement is varying between 6 and $14 \mathrm{~km}$ (Brdarević and Oluić 1979).

There are several submerged basins/depressions in which sedimentary rocks have developed, composed mostly of biogenic carbonates and evaporites. The most important depression is the Middle Adriatic Depression (MAD), characterized with crystalline basement at depths of more than $9 \mathrm{~km}$ beneath the sea floor (Figure 2). However, the deepest formation is the so called "Primorskodalmatinska depression" (Littoral-Dalmatia Depression), reaching the depth of about $14 \mathrm{~km}$ (Brdarević and Oluić 1979).

In CAD there are several different sea floor morphologies like pockmarks, mud volcanoes and mud carbonate mounds, as a result of the mobilization of gas trough fracture systems and pathways for fluid seepage, that are mostly related to present halokinetic activity of the deep, Triassic evaporite occurrences (Geletti et al. 2008). Several emerged positive structures (horsts) of the crystalline rocks have been recognized as well, such as "Primorsko-dalmatinska elevation", in which crystalline rocks are lying at depth of about $6 \mathrm{~km}$. 
Figure 2. The Structure and Morphology Map of Cristalline Rocks in the Central Adriatic

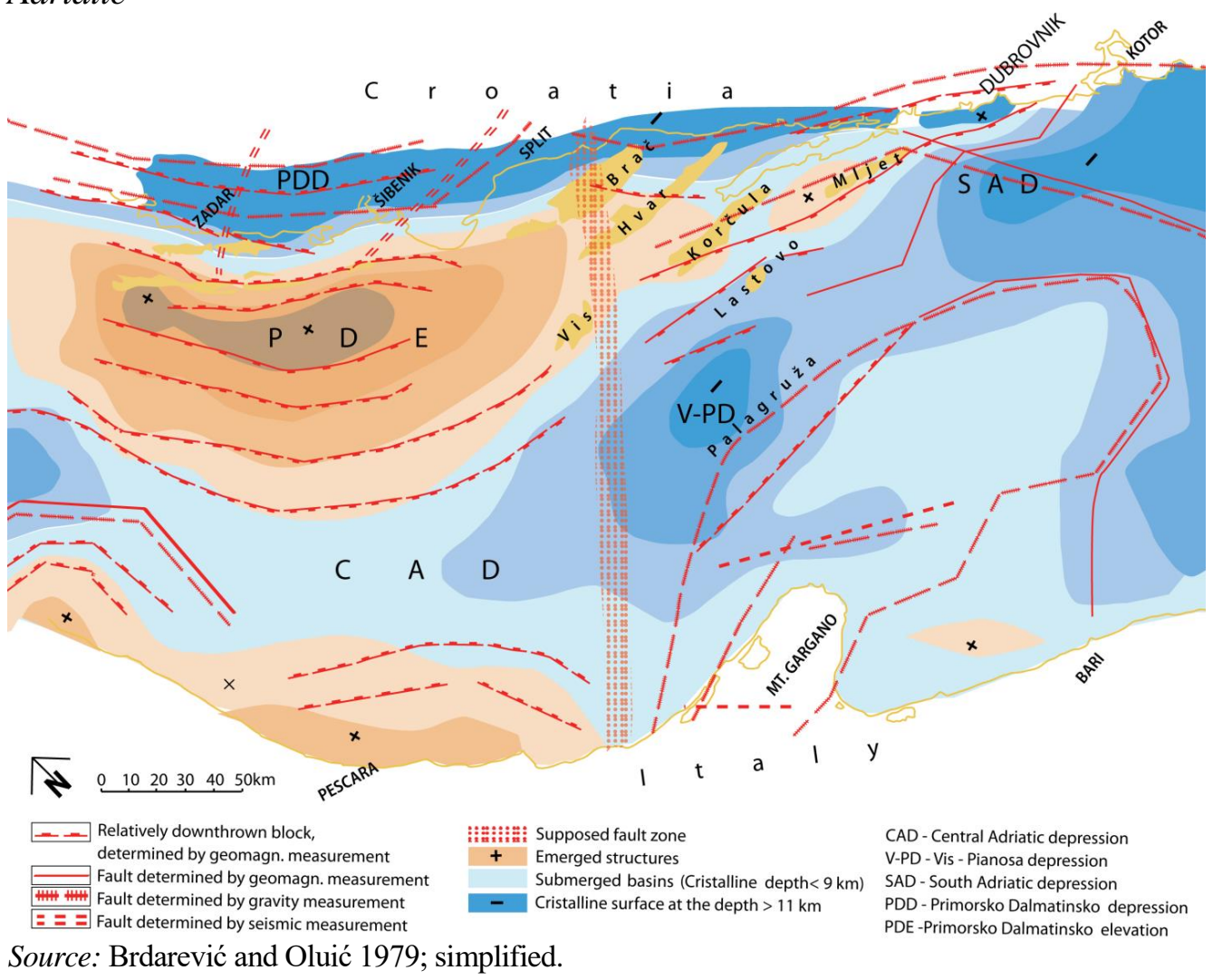

There is a number of active faults, which have a significant influence on position, and distribution of sedimentary rocks. Some blocks subsided along the vertical and subvertical faults for about $5 \mathrm{~km}$, whereas others have been moved reversely, generally in SW-verging fault system extending along the Adriatic axis. There are also transverse tectonic structures, deformation zones of regional importance. These structures have been caused by complex tectonics, by magmatism and gravity, and also by salt tectonics (Tufekčić 2015). The salt structures have typical widths of 5-10 km and they seem generally connected to thrust faults, mainly active during the Upper Pliocene (Geletti et al. 2008). Sediment diapirs occurring on the seabed associated with continuous release of gas are well known (Hovland and Curzi 1989). The salt structures are particularly important, because they act as gas seeps in the Middle Adriatic Sea (Geletti et al. 2008). The example is Jabuka Islet, where Triassic igneous bodies are extruded by salt tectonics (Pikelj et al. 2015). Due to rapid subsidence of marine basins, which occurred particularly in the Mesozoic and Neogene, very thick sedimentary deposits have been formed in places thicker than $8 \mathrm{~km}$. Permo-Triasic rocks thick about $2.5 \mathrm{~km}$ have sedimented on the basement, while Jurassic, Cretaceous, and Eocene sediments are more than $1 \mathrm{~km}$ thick (Volpi 2017). The subsidence of large Jurassic and Cretaceous blocks/basins caused the emergence of oil and gas bearing rocks, covered by very thick clastic sedimentary sequence of the upper EoceneOligocene age (Grandić et al. 1999) and thick series of Neogene sediments (Brkić 
et al. 2013). In CAD the early Quaternary and Pliocene sediments are 1-1.5 km thick (Hovland and Curzi 1989). The CAD is elongated in a NW-SE direction with thick sedimentary rocks important for hydrocarbon accumulation, since for the formation of hydrocarbon in sedimentary basins minimum sediment thickness of $2 \mathrm{~km}$ is necessary (Soloviev 2002).

The Adriatic Basin has both biogenic (microbial) and deep thermogenic petroleum systems. The Upper Triassic and Lower Jurassic source rocks in the Adriatic Sea, represented mostly by carbonates, bear oil and gas deposits (Cota et al. 2015). Triassic source rocks, composing an active Triassic petroleum system, have been sedimented in the carbonate-evaporite environment along the Croatian part of the Adriatic Basin (Cota et al. 2015).

Exploration activity in the Croatian waters of Middle Adriatic was focused on the rocks of the Creataceus carbonate platform (Wrigley et al. 2014). The oil deposits have been discovered in carbonate reservoirs at depths of 4,000-5,300 m, but according to Casero and Bigi (2013) the main reservoir can be around 1,300 m deep, below sea floor. Hydrocarbon exploration of the Middle Adriatic has been carried out since 1960s through seismic surveys and drilling (Mattavelli et al. 1991). In the period of 1955 to 80s last century, more than 190 oil and gas fields throughout the Adriatic Sea have been discovered, mostly on Italian side, and a few dozens were found in Croatian waters too (Cota et al. 2015).

The first report of a gas seep in the Adriatic Sea was gas bubbling at the sea surface off Rovinj (North Adriatic), Croatia in 1940 (Conti et al. 2002). In the northern part of Middle Adriatic large actively seeping pockmarks and hydrocarbon flows were discovered at depths of about $100 \mathrm{~m}$; the flows were emanating from depressions up to a few hundred meters wide and a few meters deep (Stefanon 1981).

In MAD- present seabed pockmarks were formed by gas whose migration was facilitated by a pre-existing pathways made by subsidence in the Jabuka Trough (Curzi and Veggiani 1985, Mazzetti et al. 1987). On the other hand, Hovland et al. (1997) suggested that most promising areas to look for resources are active mud volcanoes, such as in the area of Jabuka Islet, especially when oil and gas coexist in reservoir (Etiope 2014).

\section{Seismic Activity and Oil/Gas Migration in the Investigated Area}

The explored area of the Adriatic seabed is seismotectonically very active. Frequent earthquakes appear mostly between Richter magnitudes $M<3.0$ up to $M$ $=4.0$, but infrequently there occur earthquakes of magnitudes $M \geq 5.0$. Earthquake hypocentral depths mostly extend down to $12 \mathrm{~km}$ (Volpi 2017), but sometimes down to $15-20 \mathrm{~km}$ (Castello et al. 2006). Distribution of recent tectonically induced earthquakes of $M \geq 3.0$ is shown on the Figure 3. Generally, the highest number of earthquake epicenters grouped in several areas: west and southwest of Vis Island and southwest of Lastovo Island (Figure 3A). Most of the earthquakes, registered in the period 1985 to 2013, occurred from 2006-2013 (Figure 3B). The earthquake data coincided with increased number of registered oil slicks appearing on the sea surface in the period of our observations. This also suggest a correlation 
between oil slicks and structural features, particularly fracture zones along which pathways of fluid seepage occur, bringing oil to the sea surface.

Figure 3. (A) Spatial Distribution of Earthquake Epicenters in the Central Adriatic Occurring in the Period 1985-2013; (B) Temporal Distribution of Earthquakes of Magnitudes $M \geq 3$ from 2000-2013
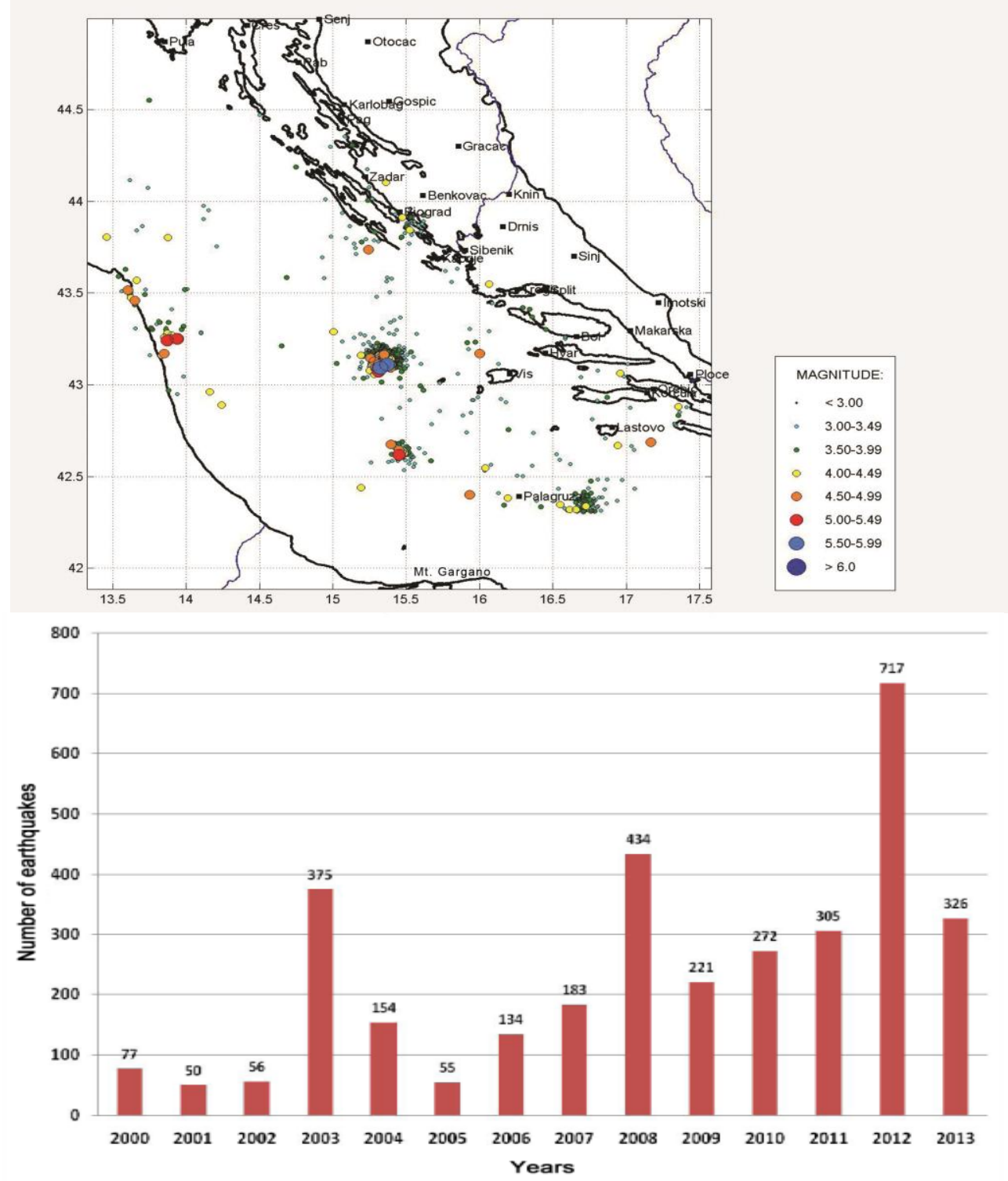

Source: Geophysical Institute “A. Mohorovičić”, University of Zagreb.

Hydrothermal fluid releases, like the formation of pockmarks, may have been triggered by activefaulting and could be associated to earthquake activity (Judd and Hovland 2007). Observations suggest that pockmarks go into an active state before and during the earthquake, showing generally higher rate of gas venting from the sea floor (Dando et al. 1995). Observations have also shown enhanced gas emission immediately prior to the earthquake (Hovland et al. 2002). Pockmarks also became active by releasing gas a few hours before a major earthquake (Judd 
and Hovland 2007). According to the same authors, the seeps are effective tools for determining whether or not a sedimentary basin has petroleum potential.

Seismotectonic activity can form vertical and subvertical faults. Often reverse slip occurs while fractures above petroleum reservoirs and seismic vibration can considerably increase the permeability due to desorption of gas from the rock matrix (Kouznetsov et al. 1994). In general, gas seepage results from the vertical migration of gas from accumulations in hydrocarbon reservoirs (Etiope 2014). The migration to the sea surface mostly occurs along fracture system.

If a petroleum reservoir is intersected by an active fault and the permeability in the fault zone increases after the earthquake, then there may be a rapid increase in the rate of upward gas/oil migration. In such a way, the gas bubbles and oil leak from the seabed towards the sea surface (Gurevich and Chilingarian 1993, Tary et al. 2012). Several authors have described gas seepages in the Middle Adriatic (Curzi and Vegiani 1985, Mazzetti et al. 1987, Hovland and Curzi 1989, Trincardi et al. 2004). However, bubblemarks are not permanent features, but are created intermittently by explosive eruptions and usually are connected to tectonic and earthquake activity. Methane gas accumulated in geological structures is buoyant and inclined to migrate towards the surface. After appearing on the sea surface, it evaporates, while oil remains for a while, being visible as oil slicks from the satellite SAR imagery (Etiope et al. 2014). Oil slicks have relatively short lives 6 48 hours (Mac Donald et al. 1993).

\section{Material and Methods}

\section{SAR Satellite Images Used in the Investigation}

Satellite SAR images have been acquired for the period 2003-2011 in the framework of an ESA project. The ESA Envisat SAR database was investigated in order to find suitable SAR images covering the Middle Adriatic. From the first analysis of Envisat SAR images (Image Mode with $\mathrm{HH}$ and VV polarization, at incidence angles $15-45^{\circ}$ and resolution 30 to $150 \mathrm{~m}$ ), about 300 were selected from the ESA catalogue of which 31 images were suitable for detection of oil slicks/spills; these were selected and analyzed in details. The analyzed set also included 3 Radarsat-2 SAR scenes obtained in 2013. The acquisition times of analyzed images is shown in the Table 1. 
Table 1. The List of Processed and Analyzed SAR Images Acquired over the Middle Adriatic for the Period 2003-2013 (Radarsat Images are Marked with Asterix)

\begin{tabular}{|c|c|c|c|c|c|c|c|c|c|}
\hline Year & Month & Day & Hour & Minute & Year & Month & Day & Hour & Minute \\
\hline 2003 & 04 & 15 & 09 & 21 & 2008 & 09 & 11 & 09 & 18 \\
\hline 2003 & 06 & 21 & 09 & 15 & 2008 & 09 & 24 & 09 & 10 \\
\hline 2003 & 05 & 04 & 20 & 41 & 2008 & 11 & 20 & 09 & 18 \\
\hline 2004 & 05 & 01 & 09 & 15 & 2008 & 11 & 20 & 09 & 18 \\
\hline 2004 & 06 & 27 & 20 & 41 & 2009 & 07 & 23 & 09 & 18 \\
\hline 2004 & 05 & 01 & 09 & 15 & 2009 & 11 & 18 & 09 & 10 \\
\hline 2008 & 05 & 07 & 09 & 10 & 2009 & 12 & 07 & 09 & 12 \\
\hline 2008 & 05 & 10 & 09 & 15 & 2010 & 08 & 28 & 09 & 15 \\
\hline 2008 & 05 & 23 & 09 & 07 & 2010 & 07 & 05 & 09 & 12 \\
\hline 2008 & 05 & 23 & 09 & 07 & 2010 & 07 & 21 & 09 & 09 \\
\hline 2008 & 05 & 23 & 09 & 07 & 2010 & 09 & 07 & 09 & 01 \\
\hline 2008 & 07 & 03 & 09 & 18 & 2010 & 09 & 13 & 09 & 12 \\
\hline 2008 & 07 & 03 & 09 & 18 & 2010 & 10 & 02 & 20 & 33 \\
\hline 2008 & 07 & 16 & 09 & 10 & 2011 & 06 & 24 & 09 & 17 \\
\hline 2008 & 07 & 19 & 09 & 15 & $2013^{*}$ & 09 & 23 & 16 & 40 \\
\hline 2008 & 08 & 04 & 09 & 12 & $2013^{*}$ & 08 & 30 & 16 & 40 \\
\hline 2008 & 08 & 04 & 09 & 12 & $2013^{*}$ & 10 & 24 & 16 & 36 \\
\hline
\end{tabular}

The Radarsat-2 SAR image acquired 2013-09-23 covered 150 x $150 \mathrm{~km}$ of marine area with spatial resolution of about $30 \mathrm{~m}$ (Scan SAR Narrow mode, pixel size $12.5 \times 12.5 \mathrm{~m}$ and incidence angles $25-30^{\circ}$ ). The other two Radarsat scenes were acquired in standard $\mathrm{W} 1$ mode, $\mathrm{VV}$ polarization and image size of $100 \mathrm{~km}$ swath width, at incidence angles $25-46^{\circ}$, and with $25 \mathrm{~m}$ resolution.

\section{Methods of Image Processing and Analysis}

Oil slicks are visible on SAR images as dark patches, because these locally decrease the sea surface roughness, and in turn the radar backscatter on the sea surface. The oil slicks detection depends primarily on three key parameters that define sea-surface backscatter. These are: wind speed, polarization modes and incidence angle.

The ability of detecting the dark features increases with the increase of radar contrast between oil spill and the surrounding water, which, in turn, is a function of spill parameters, environmental conditions, and both oil release and weather conditions. Environmental factors determine spreading, drift and weathering of oil on the sea surface. Detecting the low contrast patches depends also on the speckle noise, which are present in the images. Application of different filters decreases noise level and improves the feature detection on the image. The next step in the image processing is dark spot detection, feature extraction and oil spill/slicks/lookalike identification and classification (Brekke and Solberg 2005).

The process of the oil spill identification consisted of several successive steps. The first step in the analysis of Radarsat images was to locate the oil slicks and its contours by visual inspection using distinguishing gradients, manual delineation and threshold separation. The filters were applied in order to increase contrast and reduce speckle noise. Adaptive filters based on appropriate scene and speckle 
model are the most fitting filters for SAR images because they preserve structural and textural features. An established confidence guideline for oil interpretation (developed by MDA, Canada), has also been considered. It is based on the SAR signature in comparison to the surrounding sea state that indicates the possible presence of oil on the sea surface.

The Envisat SAR images were first processed using the ESA NEST SAR Toolbox v.5.1 software. Additional analysis of the Envisat images was performed by undersampling $3 \times 3$ pixels followed by reprojecting to geographical grid. Resampling is often sufficient for recognizing oil phenomena on the sea surface. It also allowed handling of large files so that these can be imported in GeoMixer tool (SCANEX Group: www.scanex.ru). Images are typically exported to GeoTIFF format.

After pre-processing (converting to a common format and geographical projection) and masking some elements (small islands, wind-dampening areas), the main task was detection of dark patches and bands in the images. Then adaptive thresholding was applied (Solberg et al. 1999, Solberg et al. 2003), because the radar contrast between a dark spot and the surrounding waters depends on weather conditions. Oil slicks identified on SAR images were analyzed with purpose to eliminate similar signatures generated by oil pollution of ships, biogenic slicks and other similar based on the following parameters: shape, size and aspect ratio, contrast, repetition in time and space, wind speed and contextual information. We tried to discriminate oil that originates from known sources, such as ship discharges or natural biogenous slicks.

The suspect slicks are further discriminated from look-alikes of oceanographic, atmospheric and coastal origin (Oluić et al. 2014). SAR images in GeoTIFF format were then imported to the GeoMixer and through this application the slicks were also registered, e.g. separated from homogeneous sea water. The GeoMixer allows performing of interactive analysis of geospatial data. This is a web-GIS application for collection, visualization, analysis, mapping and generation of information products based on satellite imagery. The images were imported and superimposed over geographic-bathymetric/nautical maps available in either in GeoMixer or outside. This system almost automatically generates final remote sensing products, e.g. oil spill maps, as drawn spills in additional layer. All detected oil slicks were vectorized, removed from an image background and put on the map projection. Finally, oil spill distribution layers in vector format were integrated in GeoMixer tool.

The GeoMixer allowed the mosaics to be created, as a summary of all images, merged on the bathymetric maps. All detected oil slicks from all SAR images were merged together in one layer covering the area of interest, and in such a way, the synthetic mosaic map of all detected spills was created.

At the same time the oil slicks and seep slicks were divided based on remote sensing data according to categories of probability: highly, moderately and low probable. The assigned attributes ranged from high probability (representing high confidence that the detected slick could represent oil seeps) to low probability (representing the slicks which could not represent oil seeps) as indicated through the categories of signature, morphology and detectability as highly probable, 
moderately probable and low probable. In almost all cases, the results of analysis with GeoMixer coincided with previously detected spills from visual analysis of images and processed in the NEST software.

Since the oil releases from the sea floor sources are periodic to episodic in nature, the timing of the release is not deterministic, spatial- and temporal variability of oil slicks was studied from the time series of acquired SAR images. In order to see if oil slick occurred in similar locations in different times, the mosaic of all detected spills was brought to a simple drawing tool where slicks were analyzed by years and categories, and presented as a final summary map.

Very frequently, it was possible to detect candidates for natural oil seeps from grouping or clustering (recurrent in space) of oil slicks on the sea surface as dark signatures in SAR images acquired at different dates. If these structures are repeated in time, this provides additional evidences of the release points, i.e., location of seep sources. The exact identification of the oil slick on SAR images is of mayor importance to estimate volume of the discharged oil and indicators of presence of petroleum potential in the explored area.

\section{Results}

Radarsat-2 Images from 2013

Radarsat-2 SAR image acquired on 2013-08-30 (Figure 4) was analyzed accompanied with the wind extraction for the area of interest and presented in the Figure 5.

Figure 4. Geo-Referenced Image from 2013-08-30, 16:40 UTC

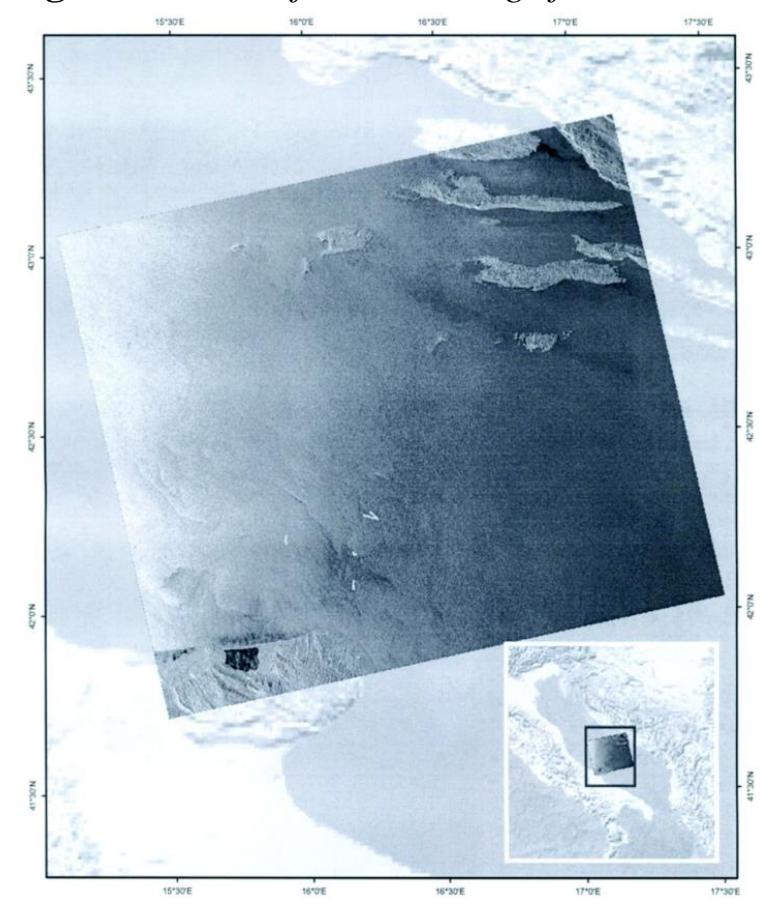

Source: (C) MDA-Geospatial Services Inc. 
Figure 5. Wind Extraction Result (Speed and Direction Values) Derived from the Radarsat-2 Image from 2013-08-30

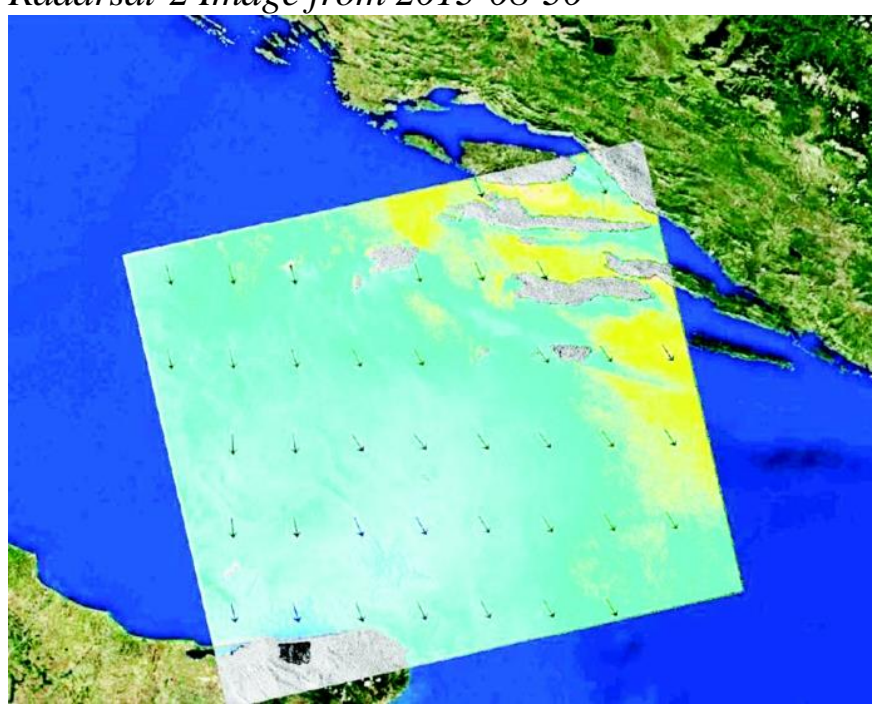

In Figure 4, a number of groups of slicks can be recognized as well as some individual slicks. Some groups of slicks definitely may be of different origin. Eventual candidates for oil seeps are mainly individual slicks, presented at enlarged segments and are marked by letters (Figure 6).

Figure 6. Enlarged Subscenes of the Radarsat Image from 2013-08-30 with Detected Oil Spill/Slicks-Dark Patches (Blue-Anthropogenic, Green-Anthropogenic or Biogenic Slicks, Red Slicks Probably Related to Oil Seeps)

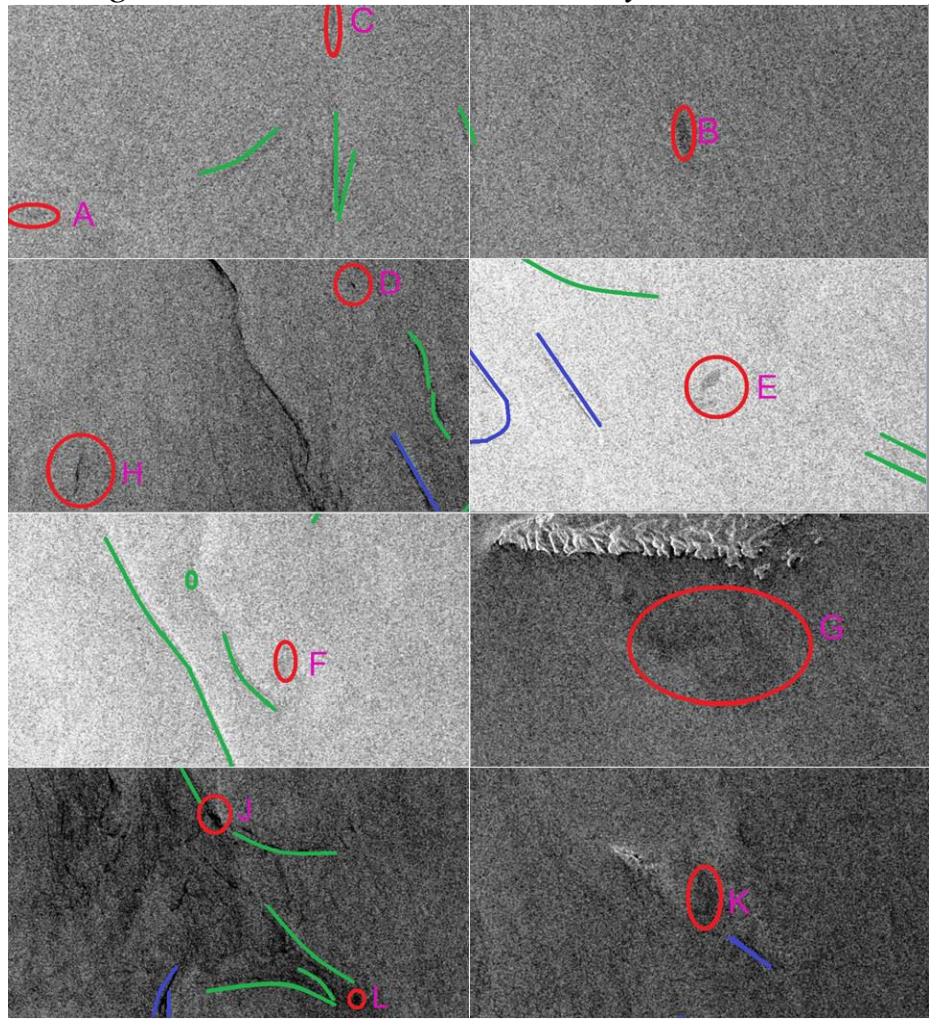


Beside a number of anthropogenic slicks and eventual biogenic slicks, it is possible to see high number of individual slicks marked in red as probable surface manifestations of oil seeps. Some of them are recognized as old once, since are spread over a larger area in the course of time, like those marked by A, B, E. Some slicks look fresh, like $\mathrm{D}$ and $\mathrm{H}$. The three processed and geo-corrected Radarsat images were imported to GeoMixer and presented (Figure 7), where the locations of slicks are show by green squares. It is visible that the oil slicks have been grouped around Vis Island and around of Palagruža Islet, northeast of Gargano.

Figure 7. Summary Map of Detected Oil Slicks from the Radarsat Images Acquired in 2013, (Green Squares) and Meteorological Stations (Black Triangles)

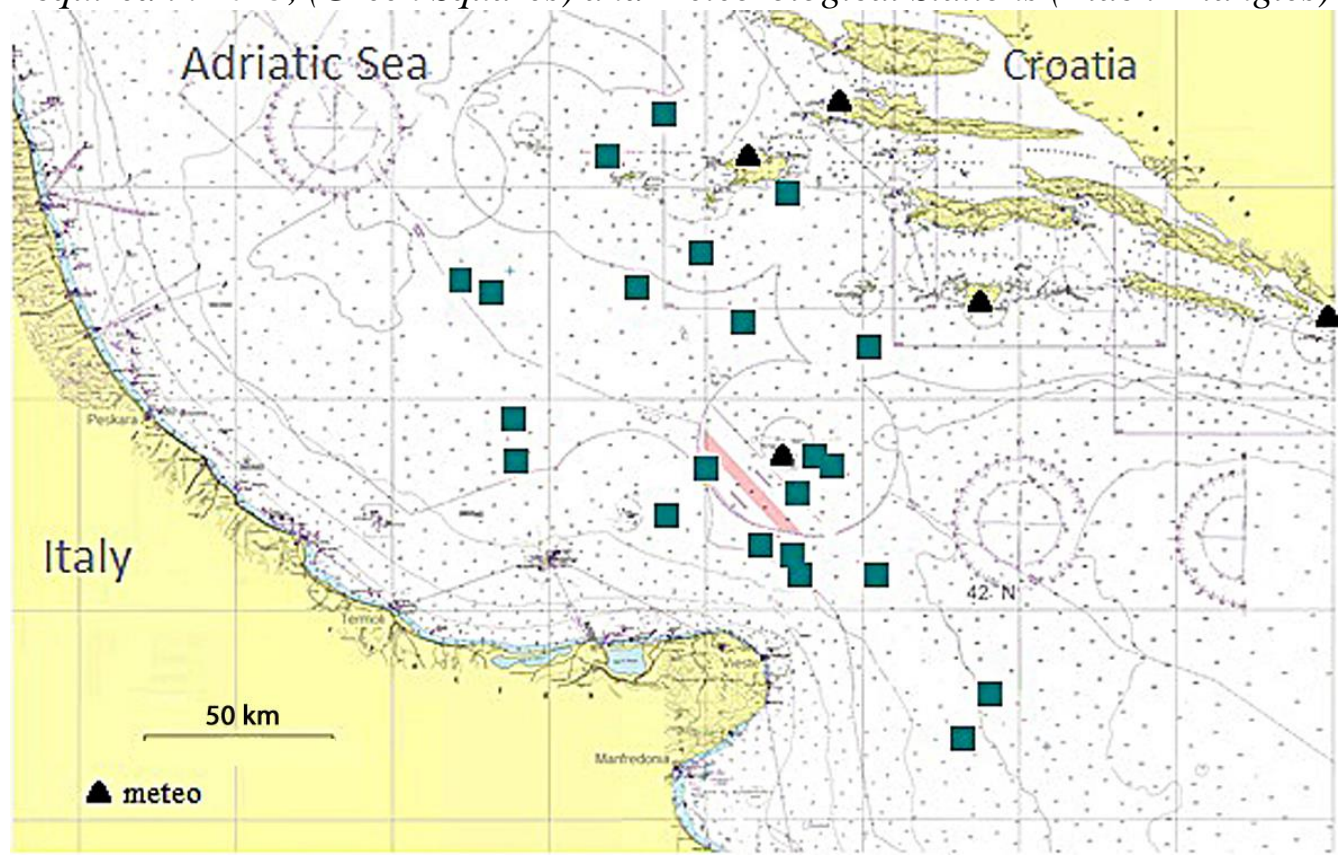

ENVISAT SAR Images from the Period 2003-2011

We selected the Envisat SAR imagery, which showed the potential oil phenomena and analysed them first via the NEST software (ESA) and latter through GeoMixer application. The software allows determination of geographical coordinates for every detected slick. It was possible to recognize many slick occurrences, although it was difficult to determine with certainty the origin of slicks. Nevertheless, on the SAR images it was possible to recognize and separate natural biogenic oil slicks from seep slicks. Focusing on every slick in every image, enlarging it several times, detailed view allowed obtaining characteristics of a particular oil slicks and attributing of their nature with some degree of probability. The GeoTIFF format images were imported to GeoMixer and through this software, the slicks were delineated.

It was noted that a number of observed slicks per image varied between images. Some SAR images have much higher number of slicks than others. Slick grouping detected in some SAR images could be indication of possible seep source. 
Detecting slicks on SAR images strongly depend on the wind speed at the sea surface. A suitable wind speed, generally between $2 \mathrm{~m} / \mathrm{s}$ and 6-7 m/s, was considered as a discriminating factor for acceptance of the images. If the wind was within the acceptable range over most of the area of interest, the SAR image is considered, and any areas of either too low or too high wind speed was in the latter phase masked-out and not used for analysis. Therefore, accompanying data for this analysis were also the wind data. Initially, for each time, when the images were acquired the wind speed was obtained from the SAR data or from meteorological stations located on the nearby islands or coast, as shown in the Table 2.

Table 2. Example of 10-minutes Average Wind Speeds, Maximum 10 Minutes Gusts $(\mathrm{m} / \mathrm{s})$ with Directions Measured at Meteorological Stations for Dates and Hours of SAR Images: 20/11/2008, 23/07/2009 and 18/11/2009

\begin{tabular}{|c|c|c|c|c|c|c|c|c|c|c|}
\hline \multicolumn{11}{|c|}{ Wind $(\mathrm{m} / \mathrm{s})$} \\
\hline \multirow{2}{*}{$\begin{array}{l}\text { Weather } \\
\text { station/ } \\
\text { time }\end{array}$} & \multicolumn{2}{|c|}{ Hvar } & \multicolumn{2}{|c|}{ Komiža } & \multicolumn{2}{|c|}{ Lastovo } & \multicolumn{2}{|c|}{ Palagruža } & \multicolumn{2}{|c|}{ Prevlaka } \\
\hline & $\begin{array}{c}10 \mathrm{~min} \\
\text { average } \\
\text { speed }\end{array}$ & $\begin{array}{l}\max .10- \\
\text { min gust }\end{array}$ & $\begin{array}{c}10 \mathrm{~min} \\
\text { average } \\
\text { speed }\end{array}$ & $\begin{array}{c}\max . \\
10- \\
\text { min } \\
\text { gust }\end{array}$ & $\begin{array}{c}10 \mathrm{~min} \\
\text { average } \\
\text { speed }\end{array}$ & $\begin{array}{c}\max . \\
10- \\
\min \\
\text { gust }\end{array}$ & $\begin{array}{c}10 \mathrm{~min} \\
\text { average } \\
\text { speed }\end{array}$ & $\begin{array}{c}\max . \\
10- \\
\text { min } \\
\text { gust }\end{array}$ & $\begin{array}{c}10 \mathrm{~min} \\
\text { average } \\
\text { speed }\end{array}$ & $\begin{array}{c}\max . \\
10- \\
\min \\
\text { gust }\end{array}$ \\
\hline \multicolumn{11}{|c|}{20.11 .2008} \\
\hline \multirow{2}{*}{ 09:10 } & 0.8 & 1.2 & 2.5 & 5.5 & & & 4.5 & 4.9 & 3.4 & 5.2 \\
\hline & 45 & 62 & 343 & 338 & & & 298 & 287 & 11 & 28 \\
\hline \multirow{2}{*}{ 09:20 } & 0.6 & 0.8 & 3 & 5.5 & & & 3.6 & 5.3 & 4.2 & 5 \\
\hline & 68 & 73 & 343 & 343 & & & 298 & 281 & 28 & 11 \\
\hline \multicolumn{11}{|c|}{ 23.07.2009 } \\
\hline \multirow{2}{*}{ 09:10 } & 1.7 & 3.5 & & & 2.4 & 3.2 & 5.7 & 6.7 & 1.2 & 1.8 \\
\hline & 129 & 141 & & & 146 & 146 & 158 & 146 & 96 & 141 \\
\hline \multirow{2}{*}{ 09:20 } & 1.7 & 3.3 & & & 1.8 & 2.6 & 6.2 & 6.8 & 0.7 & 2.1 \\
\hline & 118 & 113 & & & 186 & 186 & 158 & 152 & 90 & 84 \\
\hline \multicolumn{11}{|c|}{ 18.11.2009 } \\
\hline \multirow{2}{*}{ 09:10 } & 0.2 & 0.8 & 4.7 & 5.1 & 0 & 0 & 0.5 & 3.7 & 3 & 3 \\
\hline & 124 & 118 & 343 & 338 & & & 180 & 208 & 6 & 6 \\
\hline \multirow{2}{*}{ 09:20 } & 0.6 & 0.9 & 2.5 & 4.8 & 3.1 & 3.2 & 1.1 & 2.9 & 3.6 & 6 \\
\hline & 214 & 225 & 326 & 349 & 321 & 304 & 315 & 253 & 6 & 6 \\
\hline
\end{tabular}

Source: Data from State Hydrometeorological Institute, Zagreb).

The wind data of meteorological wind fields derived from satellite images were also available through SCANEX. However, the shape and position of slicks was also strongly influenced by the sea currents.

On the Envisat SAR image from 2003-06-21 a large number of oil slicks of different forms and origin were detected (Figure 8), within the marked fields A, B, C. In enlarged parts of this image it is possible to observe sickle-like form of some 
spills, and some of them were attributed to seep manifestations. In the Table 2 it is obvious that the wind speed was within the frame of the acceptable wind-speed conditions (average $5.2 \mathrm{~m} / \mathrm{s}$ ) suitable for oil slicks detection on the satellite SAR imagery.

On the Envisat SAR image from 2011-06-24 it is possible to recognize several slicks $(1,2,3)$ of different forms and origin (Figure 9). The enlarged part of the image with oil slicks (2) is very distinctive and we recognized these as a sequence of seeps (encircled by red ellipse).

After creating mosaic of Envisat images in GeoMixer, it enabled delineating of slicks in different layers. The software allowed handling of slicks/spills independently from images and showing all slicks from different images together with a background map (Figure 10).

Figure 8. Envisat SAR Image from 2003-06-21, 09:15 UTC (A); Enlarged Areas $B, C$ and $E$ where Large Number of Oil Slicks were Detected, and Especially Enlarged Segment 8 from Area $C(D)$
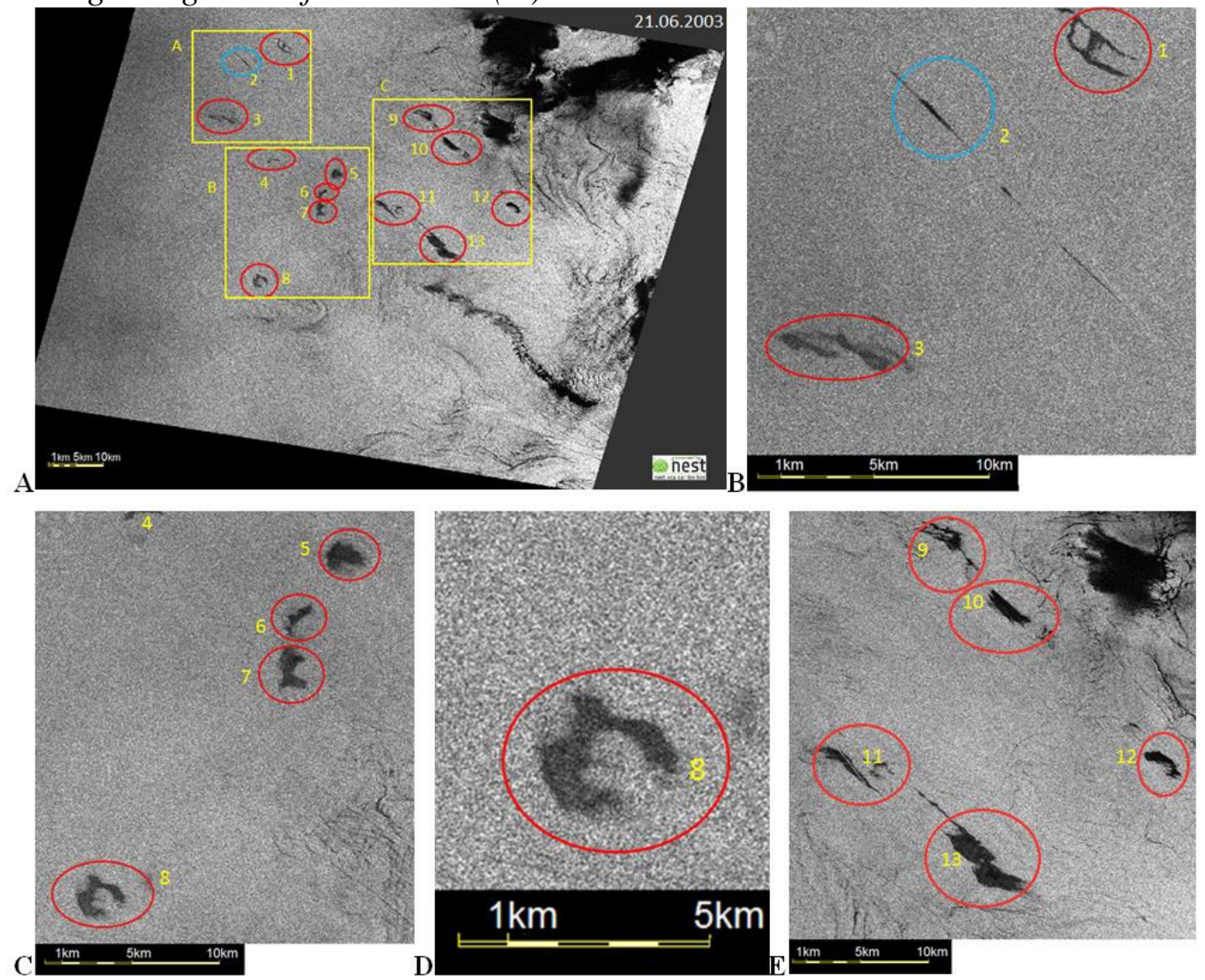

Source: (C) ESA. 
Figure 9. (Left) Envisat SAR Image (2011-06-24), 09:17 UTC; (Right) Enlarged Segment of Area 2 from the Same Image
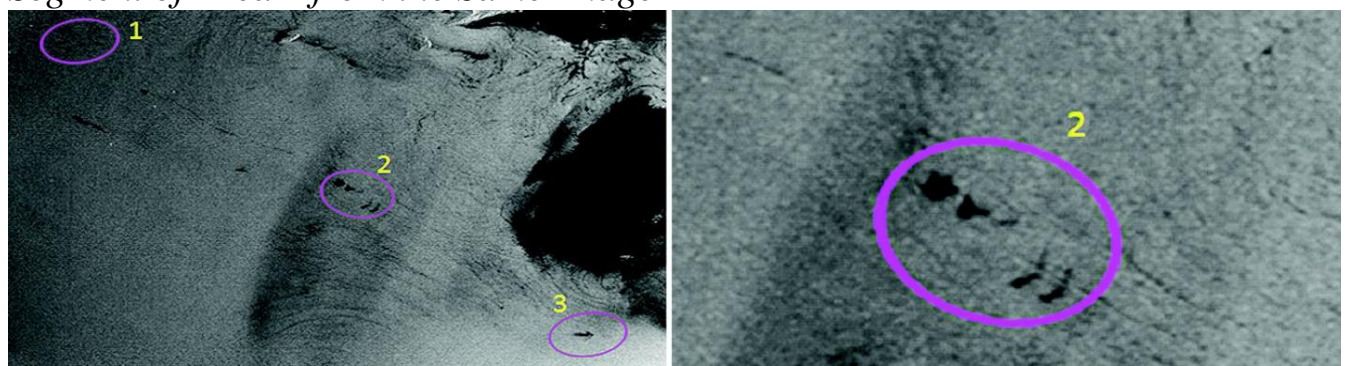

Source: ( ESA.

The advantage of this approach is that all detected spills from all images in the investigated area could be seen on a single map, in order to see better their distribution and concentration. As seen from Figure 10, prevailing direction of elongated slicks is along the long axis of the Adriatic Sea, while lower numbers of slicks are oriented perpendicular to the Adriatic axis. Beside elongated forms, many small slicks have circular or sickle-like forms.

Figure 10. (Left) Mosaic of the Envisat SAR Images with Detected Oil Slicks 20032011; (Right) Summary Map of the Same Data on the Background of Nautical Charts

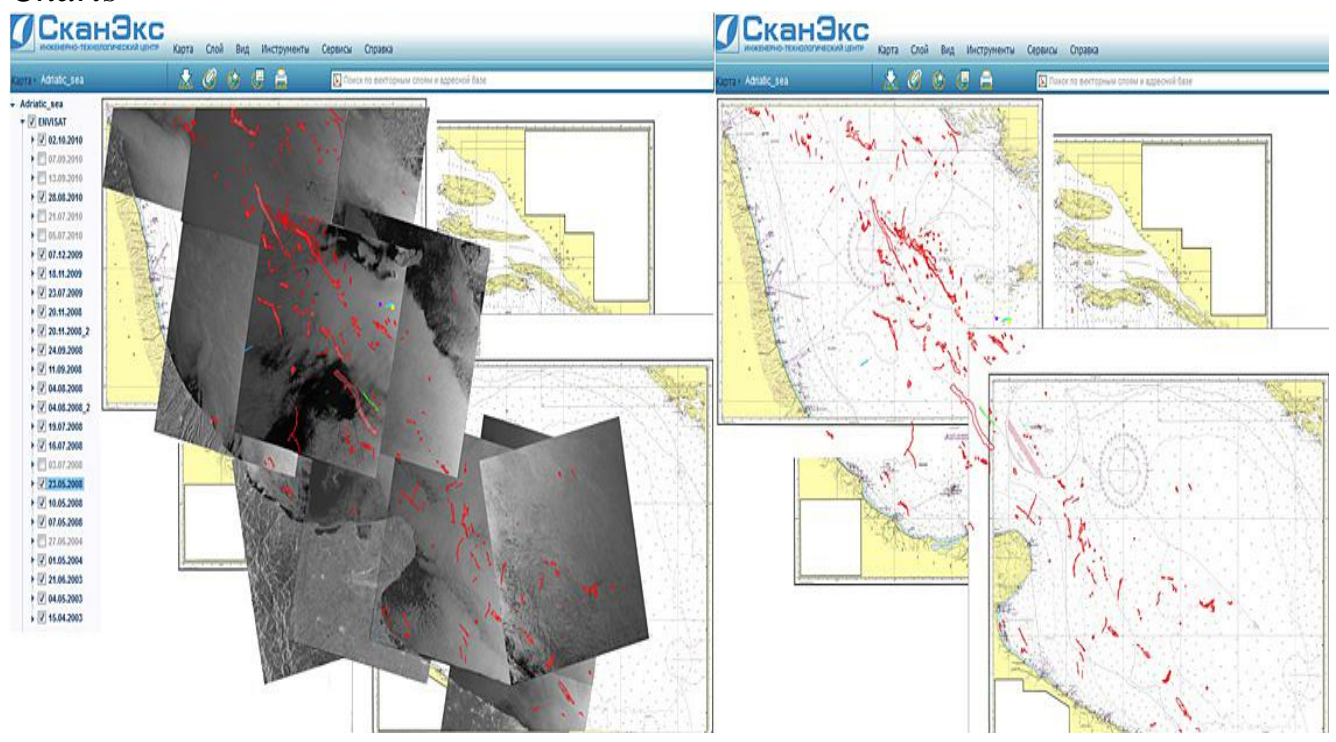

The summary map of detected oil slicks/seeps manifestations by years in the Middle Adriatic according to analysis of SAR images (Envisat and Radarsat-2) in the period 2003-2013 is shown on Figure 11. Slicks concentrate mostly in a few areas, e.g., west and southwest of Vis Island; southwest of Lastovo Island and east of Gargano. Small groups of slicks occurred also closer to the Italian coast at several locations. Based on selected criteria, it was possible to present spatial distribution of observed oil slicks/seep manifestations according to categories of probability (Figure 12). The slicks in blue color are probably from anthropogenic, ship origin. They mostly have elongated shape and are distributed along the long 
Adriatic axis. Green colored slicks, distributed both along the Adriatic axis as well as transverse to the long axis, came also mostly from anthropogenic origin (fishing vessels or else). Most probable seep manifestations, shown in red, have the smallest size and are distributed mostly in the middle part of the Adriatic Sea.

It is obvious that some of the registered oil occurrences belong to the anthropogenic origin, but it is also clear that a part of them could have natural origin, either are natural biogenic films of planktonic origin or from natural seeps at the sea floor, which was of our primary interest. In order to be sure which one among registered oil slicks on SAR images are seep manifestations it would be necessary to analyze continuous flow of satellite SAR images acquired during a longer period of time and perform in situ sampling for chemical analysis.

Figure 11. Summary Map for the Middle Adriatic of Detected Oil Slicks and Possible Seep Manifestations by Years, Based on the Analysis of Envisat and Radarsat-2 SAR Images for the Period 2003-2013

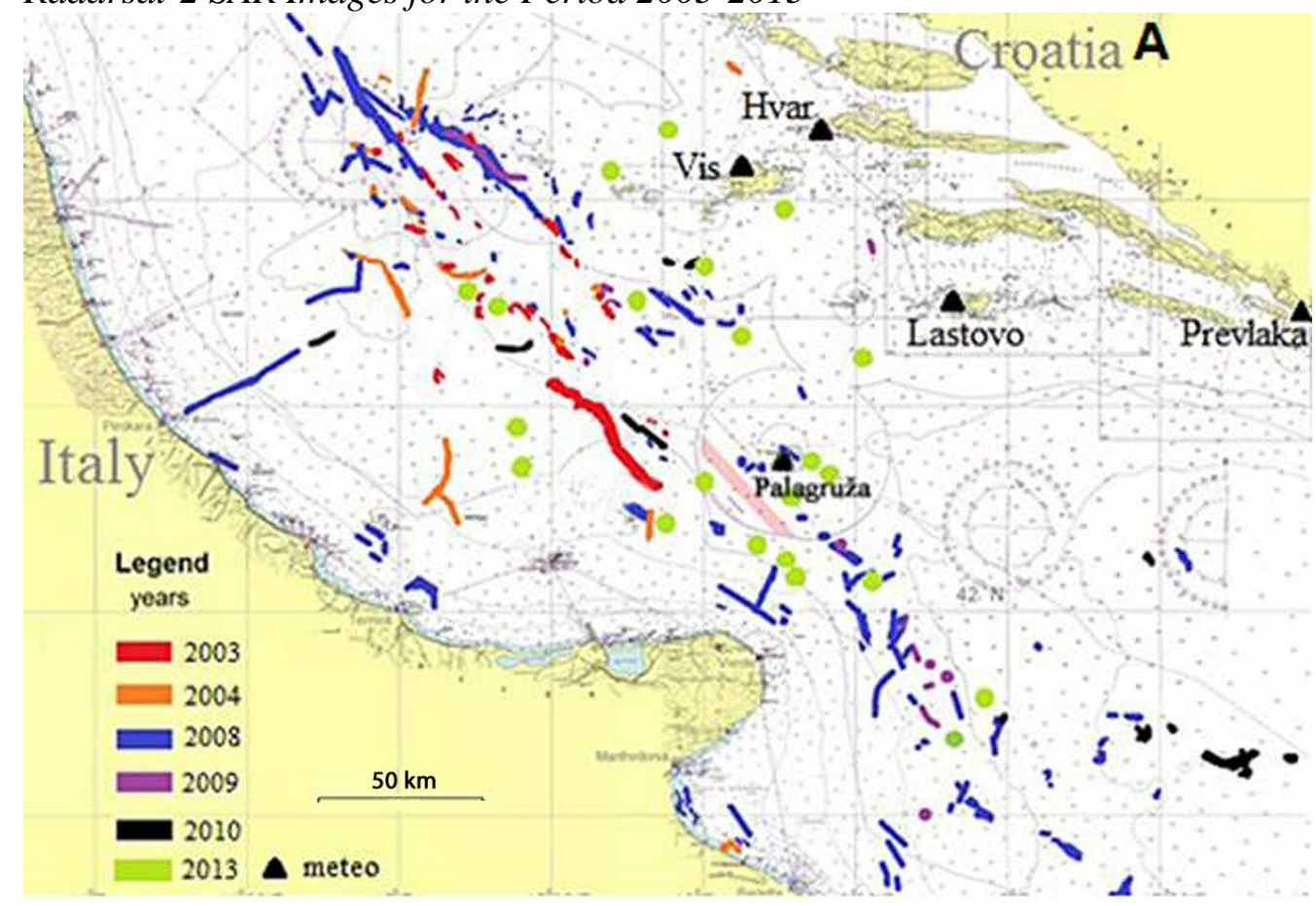


Figure 12. Summary Map for the Middle Adriatic of Detected Oil Slicks and Possible Seep Manifestations by Categories, Based on the Analysis of Envisat and Radarsat-2 SAR Images for the Period 2003-2013

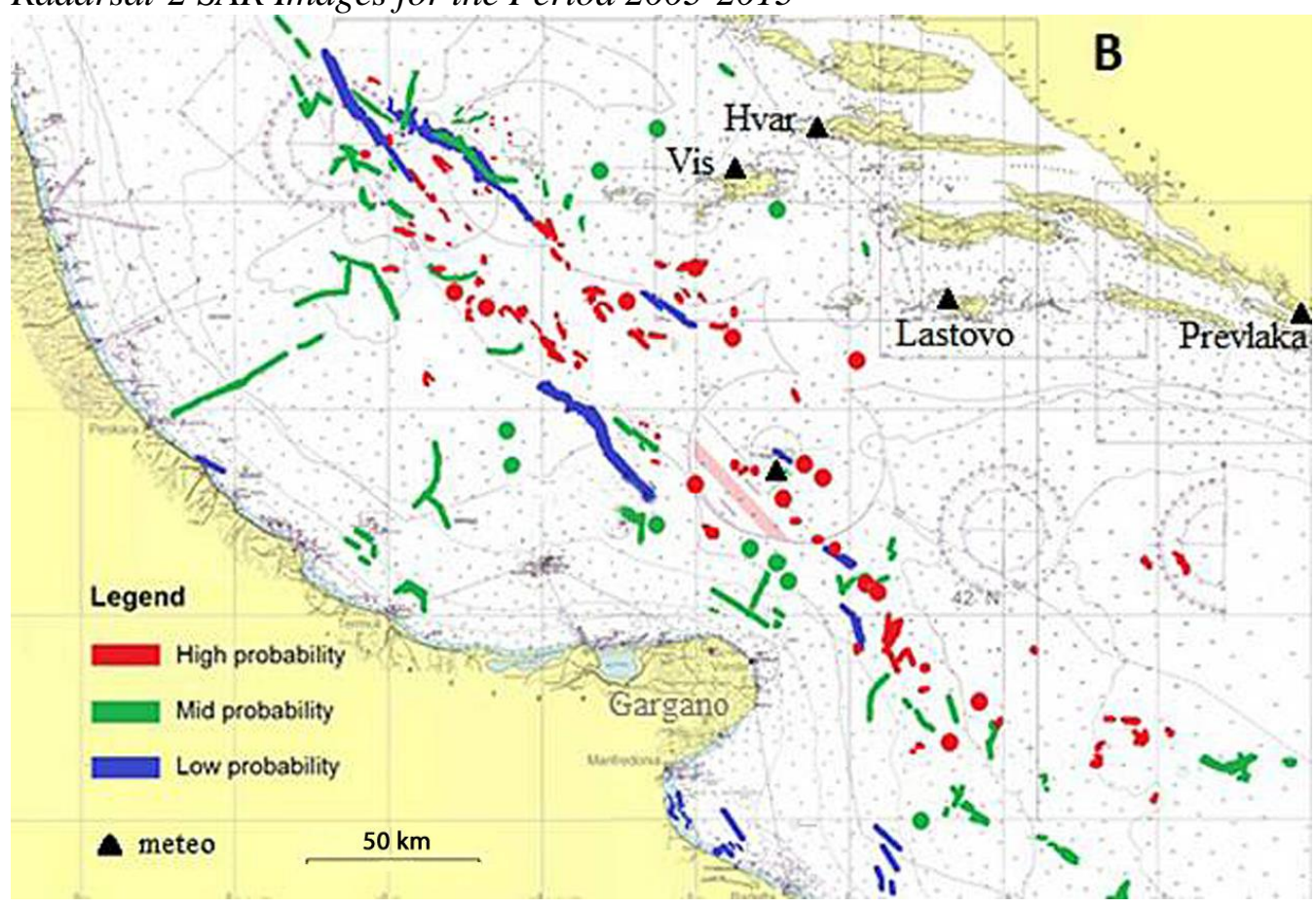

Oil Slicks and their Connection to the Seismotectonic Activity

The correlation between oil slicks concentration and tectonic structures and epicenters of earthquakes in the Middle Adriatic indicates that there is a connection between local tectonic ruptures, earthquake epicenters and oil slick phenomena since these occur most often along the brinks of the step-like East side of Middle Adriatic submarine depressions.

The basement of sedimentary rocks, i.e., the crystalline complex beneath the Adriatic Basin, is morphologically well expressed. It is characterized by many submerged depressions and emerged structures. The most important depression is CAD, oriented NW-SE (Figure 12). 
Figure 13. The Structure and Morphology Map with Isobaths of Cristalline Rocks and possible Oil Slick Fields $(A, B, C, D)$ in the Middle Adriatic

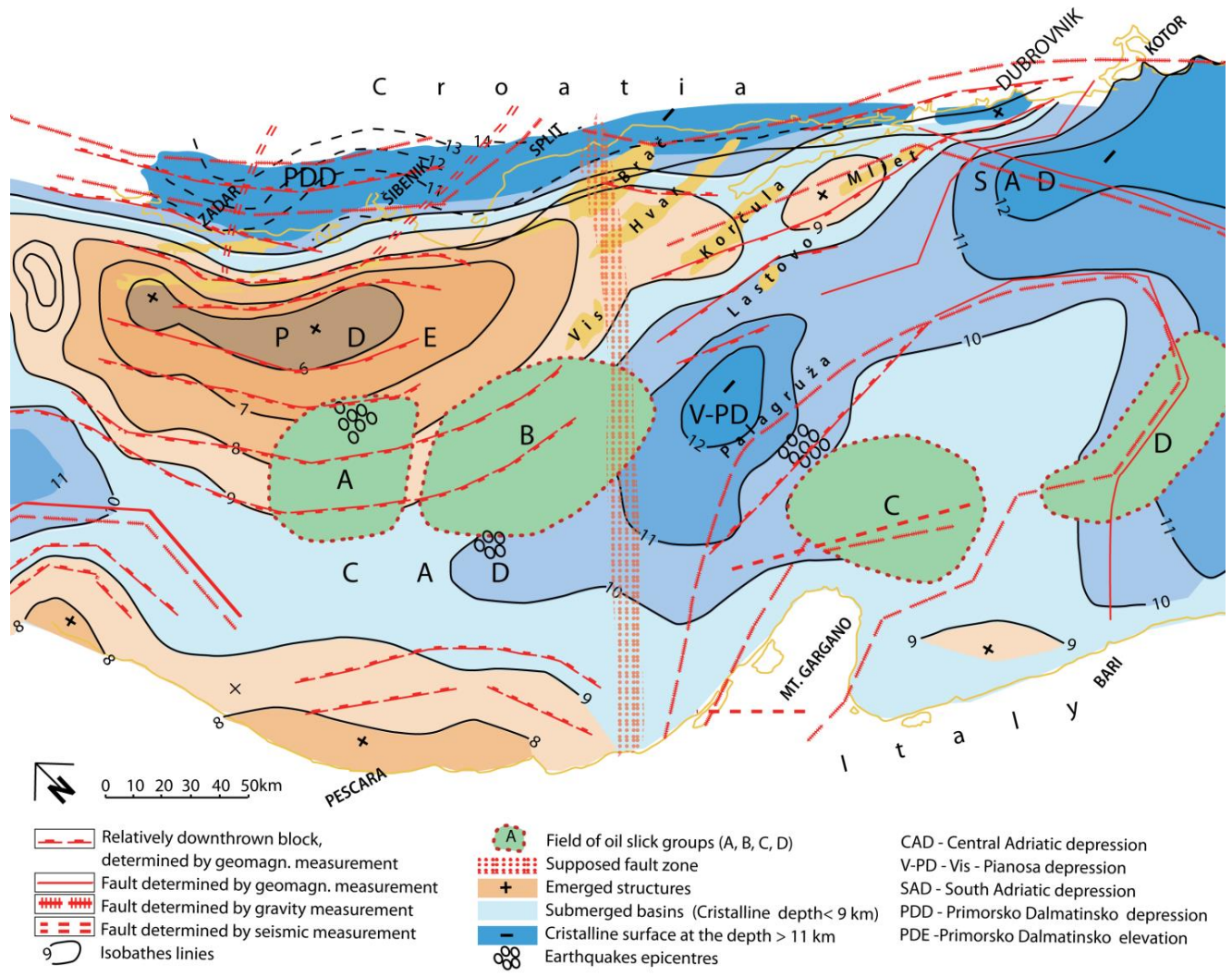

Source: Brdarević and Oluić 1979; simplified.

This depression has been formed by activity of numerous faults stretching along the eastern part of the Adriatic depression. By the parallel faulting, there developed a gradually-stepwise profiled submarine slope, directed towards the central part of the depression where crystalline rocks lie at depths of more than 9 $\mathrm{km}$ (the seabed depth varies in that region from 0 down to $190 \mathrm{~m}$ ). The CAD is well separated by the regional transversal deformation zone Gargano-Split from the Vis-Pianosa Depression (V-PD).

The oil slicks are grouped in four fields (Figure 13). It is presumed that the concentration of registered oil slicks is connected to the local fracture system, whose earthquake activity enabled formation of pathways for liquid hydrocarbons (Field A). The group of oil slicks observed southwest of the Vis Island lies on the brink of the step-like profiled slope zone, formed by faulting, and associated to seismically active Field B. In the two fields east of Gargano, numerous oil slicks have been determined (Fields $\mathrm{C}$ and D). The Field $\mathrm{C}$ is situated between faults on the brink of V-PD. It is also associated with a remarkable seismic activity. Somewhat east of that field lies the Field D. It is characterized by the concentration of oil slicks extending along the fault, on the brink of South Adriatic depression. The sea depth at both fields and surrounding area ranges between 120 $1,200 \mathrm{~m}$. 


\section{Conclusions}

The Envisat and Radarsat-2 SAR images have been used for slicks/seeps detection and their mapping in the Middle Adriatic, determining their frequencies and approximate oil leak sources. For these purpose a series of 34 SAR images acquired through the period of 10 years (2003-2011 and in 2013) have been processed and analysed.

In the Middle Adriatic, the sedimented rocks consist mostly of carbonate and evaporites with sources and reservoirs bearing hydrocarbons. Seismotectonic activity formed vertical and sub-vertical faults and fractures which can create pathways for fluid seepage so that gas and oil can migrate from seabed to the sea surface.

The oil slicks identification on satellite SAR images was performed by differing contrasts between the surface slicks and surrounding clear sea water. Using GeoMixer tool it was possible to register and separate slicks of different origin and determine their main characteristics.

Analyses of spatiotemporal distribution of oil slicks on satellite images enabled detecting of hot spots with persistence and temporal recurring in the same locations that indicates the presence of natural seeps.

Oil slicks were assigned according to the developed confidence levels of high, mid or low probability. The registered oil slicks and possible seeps were sorted by years and by categories of probability. Most slicks were of anthropogenic origin, but recurrent slicks at some places indicate natural seepage phenomena in the Middle Adriatic. The registered seepage slicks were concentrated in several fields. These phenomena were linked to local active faulting and associated earthquake activity which created pathways for fluids, gas bubbling and oil seeping. That can be an important indicator of hydrocarbon accumulations in the seabed. Our results suggest that annual seepage rates in the Middle Adriatic require further a systematic investigation of an extensive SAR time series.

\section{Acknowledgements}

Authors are very grateful to INA-Oil Co., Zagreb, Croatia, who partially supported this work (No: SN-1138/13). We also acknowledge the European Space Agency (ESA) for providing the Envisat SAR images through the ESA research project \#19234 (PI M. Oluić). The work of Russian co-author was supported by the state assignment of the Russian Federal Agency of Science Organizations, theme No. 0149-2019-0003.We thank SCANEX Group (Russia) for opportunity to use GeoMixer application and web resources for processing and analysis of SAR images. 


\section{References}

Akar S, Lutfi Süsen M, Kaymakci N (2011) Detection and object-based classification of offshore oil slicks using Envisat-ASAR images. Environmental Monitoring Assessment 183(1-4): 409-423.

Battaglia M, Murray HM, Serpelloni E, Bürgmann R (2004) The Adriatic region: an independent microplate within the Africa-Eurasia collision zone. Geophysical Research Letters 31(9): L09605.

Bayramov E, Kada M, Buchroithner M (2018) Monitoring oil spill hotspots, contamination probability modelling and assessment of coastal impacts in the Caspian Sea using SENTINEL-1, LANDSAT-8, RADARSAT, ENVISAT and ERS satellite sensors. Journal of Operational Oceanography 11(1): 27-43.

Brdarević N, Oluić M (1979) Contribution to the knowledge of tectonic structure of the Adriatic Sea bottom. Proceedings of the Faculty for Mining-Geology-Petroleum Engineering, University of Zagreb, on the Anniversary of the Establishment 19391979, 1-14.

Brekke C, Solberg AHS (2005) Oil spill detection by satellite remote sensing. Remote Sensing of Environment 95(1): 1-13.

Brkić V, Križ J, Omrčen B, Bejdić G (2013) Projekt Južni Jadran i primjena suvremenih tehnoloških dostignuća pri izradi istražne bušotine u podmorju dubokog mora (The project Southern Adriatic and application of recent technological achievements during experimental drilling in deep water seabed). Naftaplin: Znanstveno-stručno glasilo Hrvatske udruge naftnih inženjera i geologa 75: 54-74.

Casero P, Bigi S (2013) Structural setting of the Adriatic basin and the main related petroleum exploration plays. Marine and Petroleum Geology 42(Apr): 135-147.

Castello B, Selvaggi G, Chiarabba C, Amato A (2006) Catalogo della sismicita. 19812002 ver.1.1 (Seismicity catalogue 1981-2002 ver.1.1). Roma, Italy: Instituto Nazionale di Geofisica e Vulcanologia - CNT.

Conti A, Stefanon A, Zuppi G (2002) Gas seeps and rock formation in the northern Adriatic Sea. Continental Shelf Research 22(16): 2333-2344.

Cota L, Troskot-Čorbić T, Koch G, Pandžić M (2015) "Burno" facies as a key factor in hydrocarbon exploration of Middle and South Adriatic. Proceedings of $8^{\text {th }}$ International Conference and Exhibition on Oil and Gas Management, Šibenik, Croatia, 13-16 June 2015. Croatian Association of Mining Engineers No. 143-144, 71-78.

Curzi VP, Veggiani A (1985) I pockmarks nel mare Adriatico centrale (The pockmarks in the central Adriatic Sea). L'Ateneo Parmense. Acta Naturalia 21: 79-90.

Dando PR, Hughes AJ, Leahy Y, Niven JS, Taylor JL, Smith C (1995) Gas venting from submarine hydrothermal areas around the island of Milos, Hellenic Volcanic Arc. Continental Shelf Research 15(8): 913-929.

Devoti R, Ferraro C, Gueguen E, Lanotte R, Luceri V, Nardi A, Pacione R, Rutigliano P, Sciarretta C, Vespe F (2002) Geodetic control on recent tectonic movements in the central Mediterranean area. Tectonophysics 346(3-4): 151-167.

Etiope G (2014) Natural gas seepage: the earth's hydrocarbon degassing. Springer. ISBN=978-3-319-14600-3. DOI=10.1007/978-3-319-14601-0.

Etiope G, Panieri G, Fattorini D, Rgoli F, Vannoli P, Italiano F (2014) A thermogenic hydrocarbon seep in shallow Adriatic Sea (Italy): gas origin, sediment contamination and benethic foraminifera. Marine and Petroleum Geology 57: 283-293. 
Evtushenko NV, Ivanov AY (2013) Oil seep manifestations in the southeastern Black Sea studied using satellite synthetic aperture radar images. Izvestiya, Atmospheric and Oceanic Physics 49(9): 913-918.

Friedman KS, Pitchel WG, Clemente-Colon P, Li X (2002) GeoMEx - an experimental GIS system for the Gulf of Mexico region using SAR and additional satellite and ancillary data. Proceedings of International Geoscience and Remote Sensing Symposium (IGARSS'02). IEEE International. DOI=10.1109/IGARSS. 2002.1027 177.

Geletti R, Del Ben A, Busetti M, Ramella R, Volpi V (2008) Gas seeps linked to salt structures in the Central Adriatic Sea. Basin Research 20(4): 473-487.

Girard-Ardhuin F, Mercier G, Garello R (2003) Oil slick detection by SAR imagery: potential and limitation. Proceedings of the Marine Technology and Ocean Science Conference OCEANS 2003, 22-26 September 2003, San Diego, USA.

Grandić S, Boromisa-Balas E, Susterčić M, Kolbah S (1999) Hydrocarbon possibilities in the Eastern Adriatic Slope zone of Croatian offshore. Nafta 50(2): 51-73.

Gurevich AE, Chilingarian VG (1993) Subsidence overproducing oil and gas fields, and gas leakage to the surface. Journal of Petroleum Science and Engineering 9(3): 233238.

Hovland M, Curzi P (1989) Gas seepage and assumed mud diapirism in the Italian Central Adriatic Sea. Marine and Petroleum Geology 6(2): 161-169.

Hovland M, Gallagher VJ, Clennell BM, Lekvan K (1997) Gas hydrate and free gas volumes in marine sediments: example from the Niger Delta front. Marine and Petroleum Geology 14(3): 245-255.

Hovland M, Gardner JV, Judd AG (2002) The significance of pockmarks to understanding fluid processes and geohazards. Wiley Editing Services. Geofluids 2(2): 1-36.

Hu C, Li X, Pichel WG, Muller-Karger FE (2009) Detection of natural oil slicks in the NW Gulf of Mexico using MODIS imagery. Geophysical Research Letters 36(1): L01604.

Ivanov AY (2012) Unique phenomena in Lake Baikal, Russia imaged and studied with SAR and multi-sensor images. International Journal of Remote Sensing 33(23): 7579-7598.

Ivanov AY, Zatyagalova VV (2008) A GIS approach to mapping oil spills in a marine environment. International Journal of Remote Sensing 29(21): 6297-6313.

Judd A, Hovland M (2007) Seabed fluid flow: impact on geology, biology and the marine environment. Cambridge University Press.

Kouznetsov OV, Sidorov IV, Katz S, Chilingarian VG (1994) Interrelationships among seismic and short-term tectonic activity, oil and gas production, and gas migration to surface. Journal of Petroleum Science and Engineering 13(1): 57-63.

Kvenvolden KA, Cooper CK (2003) Natural seepage of crude oil into marine environment. Geo-Marine Letters 23(3): 140-146.

Leifer I, Luyendyk KB, Broderick K (2006) Tracking an oil slick from multiple natural sources, Coal Oil Point, California. Marine and Petroleum Geology 23(5): 621-630.

Lušić Z, Kos S (2006) Glavni plovidbeni putovi na Jadranu (The main sailing routes in the Adriatic). Naše More 53(5/6): 198-205.

MacDonald RI, Guinasso NL, Ackleson SG, Amos JF, Duckworth R, Sassen R et al. (1993) Natural oil slicks in the Gulf of Mexico visible from space. Journal of Geophysical Research 98(C9): 16351-16364.

Mattavelli L, NovelliL, Anelli L (1991) Occurrence of hydrocarbons in the Adriatic basin. AAPG 1: 369-380. 
Mazzetti L, Segantin S, Tramontana M, Wezel CF (1987) Characteristics of pockmarks in the Jabuka Trough floor (Central Adriatic Sea). Bolletino di Oceanologia Teorica e Applicata 3: 237-249.

Morović M, Ivanov A (2011) Oil spill monitoring in the Croatian Adriatic waters: needs and possibilities. Acta Adriatica 52(1): 45-56.

Morović M, Ivanov A, Oluić M, Kovač Ž, Terleeva N (2014) Distribution and sources of oil slicks in the Middle Adriatic Sea. Proceedings of $12^{\text {th }}$ Pan Ocean Remote Sensing Conference PORSEC, 4-7 November 2014, Bali, Indonesia.

Morović M, Ivanov A, Oluić M, Kovač Ž, Terleeva N (2015) Oil spills distribution in the Middle and Southern Adriatic Sea as a result of intensive ship traffic. Acta Adriatica 56(2): 145-156.

O’Brein GW, Lawrence MG, Williams KA, Glenn K, Barrett GA, Lech M et al. (2005) Yampi Shelf, Browse Basin, North-West Shelf, Australia: a test-bed for constraining hydrocarbon migration and seepage rates using combinations of 2D and 3D seismic data and multiple, independent remote sensing technologies. Marine and Petroleum Geology 22(4): 517-549.

Oluić M, Morović M, Ivanov A (2014) On application of SAR imagery from mapping of natural oil slicks in a part of Adriatic Sea. INA-Report, Zagreb, 175.

Oluić M (2015) Earthquakes-causes and consequences with regards to Croatia and neighboring regions. Zagreb: Prosvjeta.

Pikelj K, Hernitz-Kučenjak M, Aščić Š, Juračić M (2015) Surface sediment around the Jabuka Islet and the Jabuka Shoal: evidence of Miocene tectonics in the Central Adriatic Sea. Marine Geology 359(1): 120-133.

Solberg AHS, Storvik G, Solberg R, Volden E (1999) Automatic detection of oil spills in ERS SAR images. IEEE Transactions in Geosciences and Remote Sensing 38(4): 1916-1924.

Solberg AHS, Doken ST, Solberg R (2003) Automatic detection of oil spills in ENVISAT, RADARSAT and ERS SAR images. Proceedings IGARSS. IEEE 4: 2747-2749.

Soloviev A (2002) Global estimation of gas content in submarine gas hydrate accumulations. Proceedings 6 International Conference on Gas in Marine Sediments. St. Petersburg, Russia, 2000: 123-125.

Stefanon A (1981) Pockmarks in the Adriatic Sea? $2^{\text {nd }}$ European Regional Meeting, Association of Sedimentologists, Bologna, Italy: 189-192.

Tary BJ, Gèly L, Guennou C, Henety P, Sultan N, Çağatay N, Vidal V (2012) Microevents produced by gas migration and expulsion at the seabed: a study based on sea bottom recordings from the Sea of Marmara. Geophysical Journal International 190(2): 993-1007.

Topouzelis K, Muellenhoff O, Ferraro G, Tarchi D (2007) Satellite mapping of oil spills in the East Mediterranean Sea. Proceedings of the $10^{\text {th }}$ International Conference on Environmental Science and Technology, 2007, September 5-7, Kos Island, Greece.

Trincardi, F., Cattaneo, A., Correggiari, A. and Ridente, D. 2004. Evidence of soft sediment deformation, fluid escape, sediment failure regional weak layers within the late Quaternary mud deposits of the Adriatic Sea. Marine Geology 213: 91-119.

Tufekčić D (2015) Triassic evaporate facies and their significance on petroleum prospects, mid-Adriatic basin. Proceedings of International Conference and Exhibition June 2015 on oil and gas management, Šibenik, Croatia, 143-144: 79-86.

Volpi V (2017) Geologia marina. Part I Mare Italiano-Adriatico (Marine Geology. Part I Italian-Adriatic Sea) Universita di Trieste, Anno Academico.

Wrigley R, Marszaleka A, Rodriguez K, Hodgson N (2014) Offshore Croatia-hunting 'Big Oil? In the centre of Europe- First Break 32(5): 61-68. 
Zatyagalova VV, Ivanov AY, Golubov BN (2007) Application of Envisat SAR imagery for mapping and estimation of natural oil seeps in the South Caspian Sea. Proceedings of Envisat Symposium, 23-27 April 2007, Montreux, Switzerland (ESA SP-636) Noordwijk: ESA Publication Division. 
